\title{
True West, DE SAM SHEPARD, E O LAÇO DE MOEBIUS
}

\section{Antony C. Bezerra \\ Doutorando em Teoria da literatura na UFPE}

\section{Introdução}

No plano contemporâneo, a composição artística escrita - e não apenas ela - está exposta a uma diversidade de propostas, oriundas, em grande parte, de uma crescente integração entre as artes e, especialmente, do advento de novos media, como o cinema, a televisão e o universo digital. O autor literário, figura que, em épocas anteriores, tendia a recorrer apenas à literatura como cabedal, faz uso de referências várias para a composição de seus textos, o que, se reforça o caráter multifacetado destes, também lhes confere um sentido todo novo, em que o dado subjacente pode pertencer a classes (termo que se deve entender lato sensu) de distinta cosmovisão. Desse modo, tanto a gênese do texto escrito como o inquérito que a ele pode ser empreendido estarão inscritos num universo em que as artes, longe de apresentarem apenas distinções, podem ser aproximadas sem prejuízo às particularidades cabíveis a cada canal.

Sam SHEPARD, reconhecido, hodiernamente, como um dos mais notáveis dramaturgos norte-americanos, não está imune a esse processo que propicia ao indivíduo beber das mais distintas fontes, que vão do programa de televisão à música pop. Em muitas de suas peças, também a angústia do homem contemporâneo - em especial, no contexto estadunidense - é marca dominante, em lutas que dizem respeito não apenas a encontrar um lugar na sociedade, mas, fundamentalmente, à construção da identidade.

No presente trabalho, disponho-me a enfocar uma peça de SHEPARD, publicada em 1980, que se filia a um momento em que o dramaturgo tem amplo domínio da técnica de composição do texto dramático e em que explora temáticas recorrentes de sua produção, como a frustração do American way of life e a labuta em que consiste a criação artística. Trata-se de True West.

O foco de atenção da análise que executo recai nas duas personagens principais da trama: os irmãos Austin e Lee. Observar a 
mudança de comportamento de ambos - em verdade, mais propriamente um câmbio mútuo - à luz da figura do laço de Moebius (consagrada pela xilogravura do artista holandês Maurits Cornelis ESCHER) é o objetivo-mor do trabalho. Cabe, segundo penso, justificar as duas escolhas: (1) o comportamento dos irmãos se mostra como elemento estruturante da peça, em torno do qual, de acordo com a leitura por mim levada a cabo, gravitam os demais temas e motivos; (2) a fita cujos lados direito e do avesso são indefiníveis assume ares de metáfora se posta frente a frente com os dois irmãos ${ }^{1}$.

Para fundamentar a leitura analítica do texto de SHEPARD, recorro a textos críticos que enfocam a obra do autor, fundamentalmente, BLACKBURN (2002), FAY (2002) e GILMAN (1984). Além disso, problematizo, brevemente, a questão da personagem dramática, com recorrência a PRADO (1998) e a BRAIT (1998), com menções circunstanciais à pragmática quando se observa a noção de ficção. O desenvolvimento do artigo é feito em três momentos: (1) breve exposição sobre Sam SHEPARD, sua obra e seu tempo; (2) comentários em torno do estatuto da personagem de ficção, notadamente, a do texto dramático; (3) análise propriamente dita de Austin e Lee e seu papel em True West.

\section{Plano da produção de Sam SHEPARD}

Samuel Shepard Rogers nasceu a 5 de novembro de 1943, em Fort Sheridan-IL. Logo cedo, fixa-se no sul da Califórnia, para onde a Força aérea norte-americana transferiu o pai. Antes de iniciar suas atividades no teatro, Samuel desenvolveu vários trabalhos braçais (e.g., pastor e catador de laranjas). Gostava muito da vida em ranchos, onde trabalhou cuidando de cavalos - desde cedo, mostrava grande fascinação pelos caubóis, ídolos no cinema. Abandonou a cidade em

A análise que realizo não pertence, necessariamente, ao âmago da literatura comparada. Especular em torno de um dos ramos mais prolíficos da literatura comparada - o cotejo entre as artes - está, portanto, fora de minha proposta. Isso se explica por eu não pôr num mesmo patamar a peça de Shepard e a gravura de Escher, cabendo, sem dúvidas, maiores atenções ao texto escrito. Por essa razão, não recorro a um instrumental propriamente comparatista. Apenas analiso o problema identitário dos irmãos em consonância com o Laço de Moebius II, que acaba por nada mais que oferecer uma possível ilustração do processo por que passam as personagens. 
que morava e foi para o centro de maior importância cultural dos Estados Unidos: Nova Iorque. No novo espaço, é bem verdade, não se vê um Sam SHEPARD tão disposto e à vontade quanto no Oeste, universo com que tem especial relação.

Antes de estrear como autor teatral, foi músico (chegou a ser baterista de uma banda de rock). Suas primeiras peças - ambas de um ato - datam de 1964 e foram produzidas pelo Theater Genesis: Cowboys e The rock garden ${ }^{2}$. Um ponto digno de nota de sua formação é a escassez de leituras, como o próprio autor reconheceu (FAY, 2002). Dessa forma, seu material é, muito mais, o universo das culturas dirigidas ao vulgo (cinema, música pop, televisão) que, propriamente, referências canônicas. Não aos clássicos, mas sim a James Dean, Gregory Peck, Bob Dylan ou os filmes de faroeste.

Visto como um produto da contracultura dos anos 1960, SHEPARD combina o humor a sátiras grotescas, mitos a elementos da cultura de massa. Suas personagens, de modo geral, aliam o imaginário do Velho Oeste ao presente mecanizado, numa espécie de subversão do American way of life ${ }^{3}$.

Sua primeira peça extensa foi La turista, encenada em 1967. As produções iniciais tendem a ser (em sintonia ao período histórico em que se inserem) como o efeito do consumo de drogas: surreais e perturbadoras. Conforme aponta GILMAN (1984, p.xxv), esses trabalhos, opostamente aos textos maduros, têm seu tema, muitas vezes, obscurecido, talvez como se o autor ainda tomasse pé do código dramático. Igualmente, a aparente falta de ação e de uma organicidade às peças (num estilo avant-garde) levou-o a ser muito criticado, o que fez com que, em certos momentos, tivesse dificuldades para encená-las.

Logo no início da década seguinte, em 1972, foi a Londres (com a justificativa de lá também se falar inglês, como confessou o autor a FAY, 2002), onde passou quatro anos. No início, viveu mais

2 Pode-se dizer que o desejo de Shepard em escrever peças aflorou quando, de uma vez, viu um anúncio convocando atores para uma trupe de saltimbancos. Aprovado, decepcionou-se ao constatar o quanto os atores estavam em relação de dependência aos diretores e autores. Resolveu, ele próprio, redigir os trabalhos (Fay, 2002).

3 O eletrodoméstico, elemento de considerável relevância em True West, é um índice de tal tendência. 
propriamente dos proventos levantados em corridas de galgos que de sua atuação cultural. Na capital britânica, gerou-se The tooth of crime, obra que enfoca duas estrelas do rock de gerações distintas.

O auto-exílio serviu, de certa forma, para que o dramaturgo redirecionasse sua produção na rota de peças que tratassem mais intimamente do norte-americano dos subúrbios, que ele tão bem conheceu (é o caso particular de True West). A distância fê-lo olhar para a América de forma distinta.

True West, ao lado de Buried child (primeira do gênero e que valeu o Pulitzer de 1979 ao autor) e de Fool for love, são as peças em que SHEPARD adentra uma nova temática: o drama familiar. É a essa altura da carreira que SHEPARD estréia com ator cinematográfico - no filme Days of heaven, desempenha o papel de um rancheiro (talvez nada mais apropriado houvesse...).

O dramaturgo gozou várias temporadas de sucesso no chamado circuito off-off-Broadway, em grupos como La Mama e Caffe Cino. Foi escritor oficial do Magic Theater de San Francisco por vários anos. Em 1984, teve o nome indicado para o Oscar ${ }^{\circledR}$ de melhor ator coadjuvante, pelo papel em The right stuff. No mesmo ano, recebeu a Palma de Ouro, em Cannes, pelo roteiro do filme Paris, Texas, dirigido pelo cineasta alemão Wim WENDERS. Nessa década e na seguinte, foi galardoado com várias premiações.

Sam SHEPARD é reputado como um dos maiores expoentes da dramaturgia norte-americana de hoje. Em suas mais de 40 peças, dá uma amostra de versatilidade e da ligação com elementos da cultura de massas e mesmo da Pop art. Além disso, transita por vários media, do cinema à televisão, passando pelos circuitos alternativos, o que só faz aumentar a mitologia pessoal em torno do autor. Segundo BLACKBURN (2002), flagra-se, como uma constante no que diz respeito a SHEPARD, a necessidade de se desempenhar um dado papel - nas peças e na vida. Entretanto, a tendência a se avaliar o grau de autenticidade do mundo e das pessoas leva, quase sempre, à insatisfação. Por consequiência, buscam-se novos papéis, novos mundos, novas pessoas e personagens. Daí a sucessão de experiências - na ficção e no mundo empírico. Talvez resida nesse ponto mesmo a viragem que se dá no caráter da personagem Austin, o irmão roteirista de True West. 
Ainda segundo o mesmo comentarista (BLACKBURN, 2002), está, no cerne das manifestações artísticas de SHEPARD, a busca pela identidade. Ela, quase sempre, associa-se à ansiedade das personagens em percebê-la. Não é, no entanto, uma construção de natureza pacífica, pois que a contradição é um Leitmotiv na criação do autor. O que anseiam suas personagens, não se sabe ao certo. A ligação de suas figuras ao mundo californiano, a título de exemplo, mostra, sempre que se tenta dar um passo à frente, um recuo. Pela tensão derivada, as personagens tendem, quase sempre, ao conflito, a berrar, a brigar, a xingar. A violência de seu trabalho advém, em grande parte, do mundo que é retratado (é provável ser esse o ponto central a favorecer a detecção de um certo realismo em SHEPARD).

Da simplicidade aparente dos enredos que empreende, emanam elementos míticos, que subjazem às gags (como se esquecer, em True West, dos dentes do Velho e da fila de torradeiras que roubou Austin?) e à superficialidade dos dramas humanos apresentados. O processo de fragmentação de uma sociedade infeliz também é desvendado pelo dramaturgo. No fim de contas, os muitos rótulos fixados em SHEPARD acabam por ser, todos eles, plausíveis: "surrealista", "gótico", "mítico-realista" etc. (GILMAN, 1984, p.xi). É bem certo ser esse caráter multifacetado proveniente do desejo do autor manifesto a FAY (1984):

Acredito estar sempre ansiando por uma peça que será responsável por suprir plenamente a minha necessidade de escrever peças. O tipo de coisa definitiva. Mas isso nunca acontece. Sempre há desapontamentos, algo que está faltando, algum nível ainda não alcançado, e, quanto mais você escreve, mais você luta, mesmo se estiver numa vaga de inspiração. [...] Então você vai e tenta outra peça. $^{4}$

No fim de contas, é um percurso não despido de acidentes, em que o multiartista parece estar à procura de quem será - ou de quem serão? - Sam SHEPARD. É possível que, como o escritor português Fernando PESSOA, precise ser muitos para ser um só, para ser, sobretudo, autêntico.

4 Esta passagem bem como todas as outras originalmente em inglês (inclusive o texto dramático) foram por mim traduzidas. 


\section{Apreensão ficcional do mundo empírico. A personagem do texto dramático}

No plano de discussões vulgares, nada mais comum que traçar uma oposição polarizada - como se ausente de complexidades fosse entre realidade e ficção. A linguagem, eleita como veículo de representação de uma e de outra, teria diferentes estatutos de verdade quando se referisse a cada uma delas. Mas caberia um questionamento a tal quadro: em que medida a referência linguística a um ser humano empírico (por isso, real) seria mais palpável que aquela que se faz a uma personagem romanesca (por isso, ficcional)? Sabendo-se ser a linguagem, por excelência, convencional (embora jamais inerte) e metafórica ${ }^{5}$, representa-se, em verdade, a ausência de algo, preenchida por símbolos.

Um caminho plausível que se aponta para, por meio da linguagem, traçar-se uma distinção entre realidade e ficção é estabelecido por SEARLE (2002), que lança mão de um instrumental pragmático. De antemão, faz, o autor, uma capital observação: por serem muitas obras literárias ficcionais, julga-se que ficção e literatura implicam-se mutuamente, o que não é verdade (SEARLE, 2002, p.96). Penso ser simples estabelecer-se uma diferenciação na seguinte medida: a ficção pode ser vista como um estatuto, ao passo que a literatura carrega ares institucionais.

Num justificável reparo a Platāo, SEARle (2002, p.99) observa que a ficção não consiste em mentira, conforme pensava o filósofo grego. A razão para tal parece evidente: não há, quando se lê ficção, qualquer preocupação em um comprometimento com a verdade (mente-se, de fato, quando se finge dizer a verdade). Um romancista, ao que tudo indica, não deseja que o receptor tome a narrativa como relato fiel de fatos (é um fingimento contratual que se estabelece entre um e outro). O ponto crucial da exposição de SEARLE diz respeito à 'existência' da personagem. O estatuto dela seria de uma

Pertinentemente, levantou a questão Blikstein (1995, p.17): "Até que ponto o universo dos signos lingüísticos coincide com a realidade 'extralinguística'? Como é possível conhecer tal realidade por meio de signos lingüísticos?." Perguntas a que, felizmente, não se pode dar respostas concisas. Sobre a questão da convencionalidade da linguagem. faz-se necessário ter em conta a forma distinta como as línguas recortam o mundo empírico (elementos da natureza, tons de cor etc.). 
ontologia ficcional, ou seja, existência dentro da ficção (SEARLE, 2002, p.117). Não se trata, claro está, de uma referência a um ser empírico (como é o caso de certos elementos narrativos, a exemplo de alusões a referentes factuais - ruas, cidades, monumentos, fatos históricos etc.). Um tal estatuto se confirma quando indivíduos pertencentes ao mundo empírico referem-se a personagens ou situações ficcionais. Não se finge falar do elemento ficcional efetivamente, consubstancia-se uma alusão ao mundo ficcional (SEARLE, 2002, p.115). Impertinente (ou mentiroso) seria, a título de exemplo, afirmar que os filhos do príncipe Hamlet e de Ophelia foram assassinados, pois se sabe que o casal de namorados não gerou frutos.

Fora de dúvidas está o fato de haver conexões entre a personagem e o ser humano. Nesse processo, a mediação lingüística não pode estar senão presente. No entanto, conforme observa RIMMON-KENAN (1987, p.30-33), deve-se fazer uma síntese entre a posição mimética, ou realista (a personagem é um ser), e a purista, ou semiótica (a personagem tem um caráter meramente textual). Nem é a personagem um mero amontoado de signos circunscritos unicamente ao universo ficcional (do contrário, como se poderia, no mundo empírico, referir-se ao comportamento de Hamlet?), menos ainda um ser de carne e osso que tenha vivência independente (não cabe questionar-se, por exemplo, a respeito da infância de Hamlet: ele, simplesmente, não tem infância). Como bem resume BRAIT (1998, p.11), "as personagens representam pessoas, segundo modalidades próprias da ficção". Dentro do código ficcional, as personagens seriam espécies de equivalentes aos seres presentes no mundo empírico. Na representação lingüística de ambos, entretanto, poder-se-ia detectar um quê de aproximação.

Também se ocupou do estatuto da personagem ficcional no texto dramático o filósofo da linguagem SEARLE. Para o autor, nesse gênero, o fingimento se dá mais nitidamente entre atores e platéia que entre autor e leitor. Uma peça encenada "não é uma representação fingida [representa-se de fato] de um estado de coisas, mas o próprio estado de coisas fingido, já que os atores fingem ser os personagens." (SEARle, 2002, p.111) ${ }^{6}$. Isso se estabelece, claro está, no plano do

Corrobora essa idéia Prado (1998, p.85), segundo quem o autor de peças teatrais, para dirigir-se ao público, dispensa a mediação do narrador. comunicando-se por meio das personagens. 
código teatral (a encenação de um texto), não tanto no que diz respeito ao código dramático (o texto fixado no papel). Neste último plano, terse-iam instruções a ser seguidas numa possível encenação orientações que não consistem em fingimento.

Por seu turno, PRADO (1998) apresenta uma definição mais que apropriada da personagem teatral. Segundo o comentarista, se há um importante estatuto dessa entidade no romance (texto narrativo), no teatro, uma tal relevância se mostra ainda mais nítida, pois que, "No teatro, ao contrário [do que ocorre no texto narrativo], as personagens constituem praticamente a totalidade da obra: nada existe a não ser através delas" (PRADO, 1998, p.84). Ou seja, se, no romance, a descrição espacial e os comentários do narrador são, também, elementos estruturantes da narrativa, no teatro, a personagem é o núcleo sem que nada ocorreria.

Trata-se, a distinção operada por PRADO entre as três modalidades de caracterização da personagem, de um ponto de muito interesse a servir de base à discussão da personagem teatral. $\mathrm{Na}$ primeira forma, a personagem, por meio de suas falas, expõe o que vai em sua mente. Isso ocorreria em monólogos, solilóquios, declarações dadas a confidentes etc. (PRADO, 1998, p.91). Para o crítico de teatro, essa forma de construção da personagem soa a artificialidade (estando mesmo em desuso no teatro contemporâneo). Outra modalidade, talvez a mais natural e completa, é a ação, que "é não só o meio mais poderoso e constante do teatro através dos tempos, como o único que o realismo considera legítimo." (PRADO, 1998, p.91). A ação, bom que se diga, não se limita à movimentação no palco - engloba, inclusive, a ausência de ação (ou o silêncio). Como um homem empírico, a personagem se define mesmo pelo que faz (as pessoas não são bem o que dizem ser, e sim o que fazem). Nesse plano, detecta-se uma aproximação da noção de actante (que preenche uma função dramática). Em True West, conforme evidências elencadas no próximo tópico, observa-se que a construção de personagens - pontuadas por mudanças de postura - está firmemente vinculada a essa modalidade. A derradeira modalidade seria aquela em que a personagem é conhecida a partir do que dela se diz. Nesse tipo de apresentação, observa-se que "o autor teatral, na medida em que se exprime através das personagens, não pode deixar de lhes atribuir um grau de consciência crítica que em circunstâncias diversas elas não teriam ou não precisariam ter." (PRADO, 1998, p.94-95). Assim, deixam, as personagens, de ter autonomia para se converterem 
em títeres que atendem a funções dramáticas meticulosamente designadas pelo autor.

\section{True West e o laço de Moebius ${ }^{7}$}

A peça True West, escrita por Sam SHEPARD em 1979, subiu ao palco no ano seguinte, no Magic Theater, em San Francisco. Foi publicada pela primeira vez em 1981. Desenvolve-se em dois atos e nove cenas, quatro no "Act one" e cinco no "Act two". O número de personagens, bem como de cenários, é restrito. Dominam a cena os irmãos Austin ${ }^{8}$ e Lee', com intervenções circunstanciais do agente Saul Kimmer ${ }^{10}$ e de Mamãe ${ }^{11}$, mãe dos rapazes. O Velho, ex-marido de Mamãe e pai dos rapazes, é aludido mais de uma vez, embora não entre propriamente em cena. Funciona como uma espécie de referência ancestral para ambos. A cozinha da casa de Mamãe, além de um quarto, é onde se desenrola a trama, havendo, apenas, alusões ao mundo exterior.

7 Não é ocioso, julgo, observar que, nesta análise que ora se apresenta, deixam-se de lado elementos atinentes ao código teatral. O texto escrito (código dramático) é o único objeto de que me ocupo.

8 Roteirista plenamente integrado aos valores do mercado, sofre um processo de decadência com o desenrolar da peça. Sua aparência inicial é simples e agradável. É um escritor prático e vê sua arte como uma forma de sustentar-se e sua família. É o retrato do criador metódico e despido de paixão. Tem inveja do irmão quando este consegue estabelecer um contrato com o produtor Saul Kimmer. Passa a beber e chega mesmo a roubar. Assume o papel do irmão.

9 Indivíduo desregrado, viveu no deserto e perturba o ambiente ocupado por Austin. Tem um aspecto de indivíduo malcuidado. Consegue, por meio de uma aposta, fazer com que uma sua história (de qualidade mais que duvidosa) seja aceita pelo produtor Saul Kimmer e obriga o irmão a redigila em forma de esboço e, posteriormente, de roteiro. Vê-se como detentor de grandes idéias, contrariamente ao que pensa de si mesmo Austin. Assume o papel do escritor. De temperamento violento, consegue quase tudo por meio de ameaças.

10 Típico produtor de Hollywood, preocupa-se apenas com a possibilidade de renda dos seus trabalhos. Pretere o roteiro de amor composto por Austin em benefício da história mirabolante de Lee.

11 Surge, apenas, na última cena da peça. Entristece-se ao ver a situação lastimável em que sua casa se encontra após a ocupação dos filhos. Parece ter laivos de desvario, ao afirmar que Picasso (já morto) está na cidade. 
O enredo é mais que simples. Mamãe encarrega Austin, seu filho mais novo, de tomar conta da casa (e, especialmente, aguar as plantas) enquanto ela estiver, a passeio, no Alasca. De rompante, surge Lee, irmão mais velho de Austin e que tem um comportamento marginal. A peça começa com os dois irmãos em cena. Enquanto Austin tenta redigir um roteiro de filme, o irmão perturba o ambiente e anseia por fazer pequenos furtos na vizinhança. A viragem no comportamento de Austin - até então, de caráter íntegro - dá-se quando Saul Kimmer, produtor que compraria seu roteiro, resolve adotar, em detrimento desse texto, uma história (mais que improvável) contada por Lee, cujo cabedal de cultura é algo a se lastimar. Austin passa por um processo de decadência profunda (psicológica, física e moral) ao ser preterido, ao passo que Lee, longe de se tornar um indivíduo reto, assume o papel profissional do irmão: escritor. A tensão se estende por toda a peça até o desenlace, que, a exemplo de muitas passagens capitais da obra, é lacunar. É uma típica peça de Sam SHEPARD, no sentido de que, conforme anota GILMAN (1984, p.xviii), é trazida, arbitrariamente, para um fim em que a marca é a instabilidade. Talvez esteja mesmo, nessa característica, residente uma massiva participação autoral, que impede as personagens de galgarem qualquer 'independência' (passível de ser representada por meio de um maior aprofundamento na psique delas) - como fantoches, são movimentadas pelas mãos hábeis do dramaturgo.

O processo desencadeado pela mudança de postura (não obrigatoriamente de caráter) das personagens pode ser comparado a uma gravura do holandês Maurits Cornelis EsCHER, o Laço de Moebius II ("Figura 1"), em que nove formigas caminham por uma fita aparentemente metálica. A semelhança entre uma e outra obras

12 O matemático alemão Augustus Ferdinand Möbius foi o responsável pela concepção dos laços que passaram a receber o nome dele. Buscava, por meio disso, demonstrar particularidades topológicas. De uma tira de papel, colam-se as pontas de forma invertida, de forma que pareça ter apenas uma borda e um lado. O desenhista holandês Maurits Cornelis Escher (1898-1972), quando, em 1960, ouviu falar de um matemático inglês sobre a forma, dedicou duas xilogravuras a ela: Laço de Moebius I (1961) e Laço de Moebius II (1963), figura esta que me interessa de forma mais particular, pois que as nove formigas que caminham pelo laço oferecem a noção de ação. 
não reside, propriamente, no plano temático, mas sim do ponto de vista da estrutura. A ilusão que há entre a aparência e a essência pode iludir o indivíduo que contempla a gravura e lê a peça (ou a ela assiste). Parecem, Austin e Lee, andar em lados opostos, quando, na verdade, estão no mesmo plano. Do mesmo modo estão as formigas de ESCHER. Se acompanhadas com a ponta do dedo, vê-se que, de fato, estão num mesmo lado da fita.

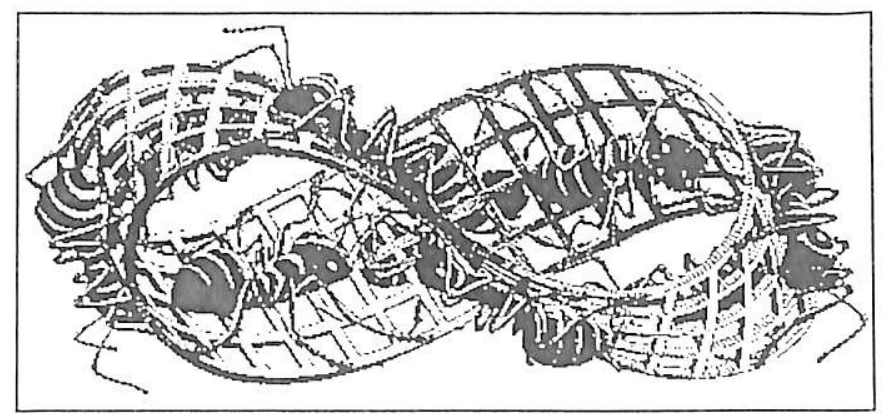

Figura 1 - Laço de Moebius II, de M. C. Escher (MOebius, 20021.

Por eu seguir o desenvolvimento comportamental das personagens ao longo da peça, bom é, inicialmente, observar a apresentação física que delas é feita antes do início das cenas. Austin, apresentado como um rapaz de trinta e poucos anos, veste roupas que aparentam ser simples. Lee está na casa dos quarenta anos e tem uma aparência de sujidade (camisa imunda, casaco coberto de poeira, sapatos esburacados, barba de dois dias e dentes cariados). Se o irmão mais novo não ostenta riqueza, surge como um indivíduo-padrão da classe média. Lee está noutro plano, com um aspecto de outsider.

O ritual da escrita, segundo a concepção de Austin, logo é apresentado na "Scene I", quando se vê sua mesa de trabalho metodicamente disposta, com o cigarro aceso no cinzeiro, um caderno de notas, uma caneta, máquina de escrever, papéis e uma vela acesa. É o criador austero, despido de arrebatamento e, sobretudo, correto. Ao mesmo tempo, está Lee, atrás do irmão, com uma cerveja na mão e já embebedado. A figura de Austin, no início da peça, muito dista daquela com que se apresentará ao termo da história; ao passo que Lee, a se tomar escritor, passará a ter uma ocupação - deixará de ser 
um ladrão -, mas não mudará de temperamento. Também nos primeiros momentos da peça é que se vê a condescendência (ou o medo?) de Austin em relação a Lee, quando aquele, tentando se concentrar e sendo interrompido pelo irmão, diz que está tudo bem se o bêbedo continuar com seu falatório inócuo (SHEPARD, 1984, p.6).

Lee em cena é sinônimo de tensão. De temperamento violento, opõe-se, decisivamente, ao comportamento inicial de Austin, que é calmo e conciliador (não se sabe se por medo, se por índole). Ainda nos primeiros momentos de interação entre os dois irmãos, logo se constata um tal quadro. Está-se na "Scene l":

AUSTIN: Você tem alguns amigos por aqui?

LEE: (ri) Sim, conheço algumas pessoas.

AUSTIN: Bem, você pode permanecer aqui pelo tempo em que eu ficar.

LEE: Eu não preciso de sua permissão, preciso?

AUSTIN: Não.

(SHEPARD, 1984, p.7).

A se impor pelo caráter transgressor - também pela força física -, Lee acaba por conseguir tudo o que deseja, por mais que Austin, fazendo uso de palavras, tente dissuadi-lo de, por exemplo, tomar o carro emprestado, roubar a vizinhança, entrar em contato com o produtor Saul Kimmer etc. Além disso, Lee quer ter benefícios - e ocorre tê-los - à maneira precisa como deseja. Quando Austin, reticente quanto a ceder aos pedidos de Lee, decide oferecer ao irmão, em vez das chaves do carro, dinheiro, Lee esbraveja, pegando Austin pela camisa:

LEE: Não diga isso a mim! Nunca mais diga isso a mim! [...] Você pode, por meio do dinheiro, afastar o Velho. Deixá-lo abastecido por uma semana. Comprálo com seu dinheiro de Hollywood, dinheiro de sangue, mas não a mim! Posso conseguir dinheiro à minha maneira. Muito dinheiro!

(SHEPARD, 1984, p.8).

Lee aparenta sentir-se ofendido com a oferta do irmão, que visa a evitar transtornos - furtos à vizinhança da mãe. Vê-se mesmo que Austin, usualmente, lança mão do seu dinheiro para afastar aquilo que afete a sua existência pacífica, caso do pai e do irmão. 
Logo após, quando Lee se encontra menos exaltado, descobrese que Austin está perfeitamente adequado às convenções sociais (contrariamente ao irmão marginal):

AUSTIN: Sabe, você podia ir ao norte comigo.

LEE: O que há por lá?

AUSTIN: Minha família.

LEE: Ah, está certo, você tem mulher e filhos, não é isso? A casa, o carro, a coisa toda. Está certo.

(SHEPARD, 1984, p.9).

O caráter dos irmãos, pode-se dizer, está delineado: Lee é um marginal com todas as letras, ao passo que Austin é o modelo do norte-americano médio: é casado, tem filhos, tem casa, carro. Sua mediocridade na criação de textos está em plena consonância com a mediocridade de sua existência. Trata-se de uma vida desprovida de sobressaltos (plenamente ajustada ao American way of life) que vê sua estabilidade ameaçada com a presença do irmão transgressor.

O deserto, cenário mítico que seduz Lee e o pai - e que, depois, também aliciará Austin - é mencionado em princípios da "Scene 2", quando Austin indaga o irmão sobre o Deserto de Mojave. É curioso notar que, como símbolo, o deserto acabará por atrair os três homens da família, sendo Austin, dos três, o neófito. O ambiente natural, dessa forma, acaba por se relacionar à mudança de caráter do irmão regrado.

A formação intelectual dos irmãos é contemplada na "Scene 2" (SHEPARD, 1984, p.11), quando Lee observa que pode adentrar a casa de pessoas proeminentes sem ser convidado (pois é ladrão) e que, para isso, não teve necessidade de freqüentar qualquer escola (dando a entender que Austin teve uma educação formal que ele, Lee, não teve).

O nascedouro da mudança no comportamento de Austin se dá quando, na "Scene 2", anuncia ao irmão que receberá o produtor hollywoodiano Saul Kimmer na casa da mãe. Um pequeno atrito se estabelece entre o escritor e o marginal, já que Lee não está inclinado a atender ao pedido do irmão: que Austin e Saul pudessem permanecer a sós para discutir o roteiro que se redigia. Lee, especialista em barganhar seus desejos, consegue ter o carro emprestado, em troca de sua ausência. 
Já na "Scene 3", quando estão o roteirista e o produtor serenamente discutindo questões atinentes à história que se compôs, retorna Lee com um televisor roubado. Começa a viragem na história: o contato que se estabelece entre Lee e Saul Kimmer acaba por arruinar a vida de Austin e por aumentar a tensão que há entre os irmãos. Após a improvável conversa sobre golfe entre o produtor e o outsider Lee, este anuncia ter uma história sobre o Velho Oeste em sua mente:

LEE: Sim, um faroeste contemporâneo. Baseado numa história real. Claro que não sou um escritor como é o meu irmão, aqui. Mas isso não faz qualquer diferença, faz?

SAUL: Em verdade, não.

LEE: Quer dizer, vários sujeitos devem ter histórias, não é? Histórias da vida real. Deve haver muitos filmes feitos a partir da vida real.

(SHEPARD, 1984, p.18).

A sugestão do homem de Hollywood, de que Austin escreva um resumo da história - a partir do relato de Lee -, ao lado de uma partida entre os golfistas, marcada para o dia seguinte, são os dois pontos que gerarão, ainda que indiretamente, a decadência de Austin. Já se está no "Act two" ("Scene 5") e, em condições mais que dúbias as lacunas que norteiam a peça -, já que a "história real" é desastrosamente fraca, Lee informa que, durante o jogo, convenceu Saul de que o faroeste é plausível e que Austin estaria incumbido de redigir o roteiro ${ }^{13}$. Num primeiro momento, Austin vê-se propenso a comemorar (queria mesmo estourar uma garrafa de champanha), mas, quando descobre que o texto de época que compõe será posto de lado em benefício do de Lee, começa a ter um comportamento que se tornará constante: o de um desequilibrado.

Austin: O que ele [Saul] disse? Conte a mim tudo o que foi dito!

LEE: Já estou dizendo! Ele disse que gostou muito da história. É o primeiro faroeste autêntico a surgir dentro de uma década.

13 Para aumentar a aura de mistério em que está envolta a questão, ventila-se um tal aposta que, sendo ganha por Lee, obrigaria Saul Kimmer a bancar o roteiro. 
Austin: Ele gostou da sua história! Da sua história?

LEE: Claro! Em que isso é tão surpreendente?

Austin: Porque é estúpida! É a coisa mais idiota de que já ouvi falar em toda a minha vida.

(SHEPARD, 1984, p.30).

É bem certo Austin ter razão. A trama é implausível a ponto de, num dado momento, dois carros que estão numa perseguição ficarem sem combustível simultaneamente. No entanto, deve-se mesmo analisar o início da mudança de comportamento verificável na personagem antes tão centrada. A convivência com o irmão (que terá a ocupação de Austin, mas permanecerá com seu comportamento marginal) muito mais ajuda a acentuar o desequilíbrio do roteirista. A inversão parcial de papéis começa a se observar.

Um ponto que, ainda na "Scene 4" de True West, indica uma forte carga de ironia dramática é aquele em que Lee tece uma observação sobre familiares, em um momento marcantemente conflitivo (quando Austin está a redigir um esboço do roteiro de faroeste para Saul Kimmer):

LEE: Pessoas de uma mesma família. Irmãos. Cunhados. O tipo de gente verdadeiramente norteamericana. Eles se matam mais quando está calor.

(SHEPARD, 1984, p.24).

A passagem, por prenunciar um possível desfecho da peça (que, stricto sensu, não se consubstancia) mostra como as personagens estão longe de ser 'independentes', se é que assim podem ser. Apresentam-se, muito mais, como entes a serviço de uma trama preconcebida e seu destino dramático está mais que traçado. SHEPARD (o autor textual) manipula as personagens, que se comportam ao belprazer de um texto que busca, tudo leva a crer, a contradição do American way of life, representado, nesse caso, pela figura de Austin, o indivíduo que, inicialmente, não é capaz de improvisar e de fugir a regras. Quando o faz, vale dizer, não chega a ser bem-sucedido.

Após todos os acertos que houve entre Saul Kimmer e Lee, Austin, num primeiro momento feliz pelo irmão, acaba por demonstrar mais um dos primeiros índices de mudança de caráter: o desejo de ir ao deserto. Ou seja, já que o irmão Lee, agora, é escritor, ele, Austin, sente a necessidade de ocupar a lacuna que se abre. 
Quando, na "Scene 6", o Sr. Kipper (no dizer de Lee) tenta convencer Austin a tomar parte no projeto novo, o revoltado roteirista se volta para o irmão e elimina qualquer espaço para que haja negociações:

AUSTIN: Eu não escrevo esse roteiro! Eu não escrevo essa droga nem para você nem para mais ninguém. Você não pode me chantagear para que eu entre nessa. Você não pode me ameaçar para que eu redija o texto. Não há meio de me fazer escrevê-lo. Portanto, os dois, desistam de me convencer.

(SHEPARD, 1984, p.34).

As palavras fortes e ressentidas de Austin mostram um homem que já está a uma distância considerável do indivíduo apaziguador e centrado que se observa no princípio da peça. As mesuras são deixadas de lado e o modo como externa seus pensamentos já está bem mais próximo da personalidade de Lee. Não se convence como Saul tenha aceitado um faroeste ("um gênero exaurido e morto") em detrimento da história de amor que se escrevia. E o curioso é notar que o próprio produtor não apresenta argumentos exatamente convincentes para expor a Austin a mudança: o tino daquele (em que tem plena confiança) é o combustível da decisão (SHEPARD, 1984, p.35).

No início da "Scene T', a mudança parcial parece estar efetuada. Enquanto o irritadiço Lee tenta, utilizando a máquina de escrever do irmão, redigir o roteiro, é atrapalhado pela cantoria mandriã do bêbedo Austin. O plano que se apresenta na "Scene I", ao menos em superfície, está invertido. O bêbedo, agora, escreve; o escritor bebe e perturba. Austin, num desejo implausível (sua 'independência' como personagem não é facilmente detectável), faz um desafio ao irmão, o novo escritor:

AUSTIN: Você acha mesmo que eu não sou capaz de roubar uma torradeira cheia de farelo de pão? Aposta quanto que eu posso roubar uma torradeira? Quanto? Vá em frente! Você é um jogador, não é? Diga-me quanto você quer casar na aposta. Uma parcela do grande adiantamento que já recebeu? [...]

(SHEPARD, 1984, p.38). 
Lee tenta demover Austin da idéia de "passear pela vizinhança' para roubar. Sua motivação maior é ter o irmão ao lado para dispor de auxílio na composição do roteiro. Austin faz troça da situação de Lee. A carga da hereditariedade - que, em momentos anteriores, perseguia apenas Lee - também se abate sobre o bêbedo Austin. O desejo por liberdade manifestado pelo ex-roteirista acaba por se tornar a motivação para um comentário do irmão: "Agora, você fala tal qual o velho" (SHEPARD, 1984, p.39). Ainda nessa cena, uma passagem que também denota a inversão de papéis: Austin conta a Lee (e não o contrário) uma história sobre o Velho - a bem da verdade, uma história que, envolvendo os dentes do pai de ambos, beira o surreal.

A consubstanciação do Laço de Moebius se observa no início da "Scene \&". A decadência moral de Austin chega ao extremo quando se constata ter roubado várias torradeiras da vizinhança da mãe. Após os irmãos discutirem em torno do que é ser criminoso - colóquio mais que inócuo -, Lee decide que tem de se encontrar com uma mulher. Após encontrar o nome de uma antiga conhecida, quer, de todo modo, conseguir o número de telefone dela. Enquanto pede auxílio a uma telefonista, destrói o que resta da cozinha de Mamãe em busca de um lápis. A decadência moral das personagens passa a rimar com a decadência do ambiente em que se inserem (e as plantas mortas, ponto central da atividade de Austin na casa, são o índice mais claro de tal). A volta no caráter de Austin se dá nas súplicas que dirige ao irmão para que partam, ambos, para o deserto (como fez o Velho). Lee, como habitual, impõe uma condição: que Austin, enfim, escreva o roteiro.

A última cena, que mostra o retorno de Mamãe a casa, acrescenta um dado à personalidade de Austin (e que era característico de Lee): a violência. No início da passagem, Austin, de fato, escreve o texto para o irmão (em condições mais que precárias, com o abandono de todo o ritual - luz de velas, máquina de escrever - que regia a atividade na "Scene l"). Fá-lo à mão porque a máquina de escrever fora destruída a tacadas por Lee. Com a chegada de Mamãe, comportam-se como garotos levados que fizeram uma traquinice, até o momento em que Austin revolta-se com o fato de Lee querer ir-se embora de carro. Instintos violentos invadem a outrora equilibrada personagem e fazem com que parta para enforcar o irmão com o fio do telefone. Mamãe choca-se com a cena e deixa a casa. Quando solta o 
irmão, Austin pensa tê-lo morto. Mas não é o que ocorre. Cai o pano após Lee fechar a passagem da porta. No jogo com as regras de Lee, Austin não é capaz de triunfar.

\section{Conclusão}

Se, na superfície, pode-se flagrar, em True West, uma aura de banalidade, aliada a uma estrutura que beira mesmo o simplório, uma leitura profunda logo denuncia que a habilidade na composição dramática, cara a Sam SHEPARD, faz-se presente nessa peça. A implausível mudança de papel que se observa entre os irmãos Austin e Lee, personagens que protagonizam a trama, longe de ter um caráter meramente lúdico, contradiz os valores que, segundo a concepção do dramaturgo, são incapazes de fazer com que o indivíduo encontre-se em sua identidade.

A leitura de True West, baseada na inserção da peça no plano da obra do dramaturgo e em especulações em torno da personagem dramática, que empreendi neste trabalho expôs - ao menos, disso tenho esperanças - a forma complexa como se constroem as personagens shepardianas, bem como uma ilustração visual de tal processo (a gravura de ESCHER por mim trazida à baila).

Longe de intentar uma leitura definitiva da peça - que, como disse, pauta-se por um intrincado sistema de referências e alusões -. observo, por meio de minha modesta contribuição, o estatuto das personagens e, especialmente, a forma como evolui seu caráter em consonância com o ambiente em que vivem. Se o seguimento de uma vida plenamente regrada pode aparentar realização pessoal, qualquer abalo nessa frágil estrutura - e aqui penso, particularmente, no ambiente norte-americano - é capaz de desestruturar a postura reta do indivíduo. Configura-se uma espécie de desmascaramento do exaltado American way of life. 


\section{Referências bibliográficas}

BralT, Beth. A personagem. 6. ed. São Paulo: Ática, 1998.

BLACKBURN, John. Portrait of the artist: Sam Shepard ant the anxiety of identity. Disponível em

$<$ http:88xroads.Virginia.edu/ MA95/blackbrn/toc.html>. Acesso em 23 jul. 2002.

BLIKSTEIN, Izidoro. Kaspar Hauser: ou a fabricação da realidade. 7. ed. São Paulo: Cultrix, 2001.

COElho, Ruy. Ficção e realidade. Disponível em $<$ http://www.eca.usp/associa/cesa/revista4/ficcaorealidade.html>. Acesso em 27 dez. 2002.

ERnst, Bruno. O espelho mágico de M.C. Escher. Berlin: Taschen, 1991.

FAY, Stephen. Sam Shepard. Disponível em $<$ http://dspace.dial.pipex.com/town/parade/abj76/

PG/pieces/sam_shepard.shtml>. Acesso em 23 jul. 2002.

GILMAN, Richard. Introduction. In: SHEPARD, Sam. Seven plays. [s.l.]: Bantam, 1984. p. xi-xxvi.

MoEbius Strip. Disponível em

$<$ http://www.uvm.edu/ mstorer/escher/moebius.html>. Acesso em 7 ago. 2002.

PRADO, Décio de Almeida. A personagem no teatro. In: CANDIDO, Antonio (org.). A personagem de ficção. 9. ed. São Paulo: Perspectiva, 1998. p. 81-101.

RIMMON-KENAN, Shlomith. Narrative fiction: contemporary poetics. London: Methuen, 1987.

RosenfELD, Anatol. Literatura e personagem. In: CANDIDO, Antonio (org.). A personagem de ficção. 9. ed. São Paulo: Perspectiva, 1998. p. $9-49$.

SAM Shepard. Disponível em <http://www.imagi-nation.com/moonstruck/clsc41.html. Acesso em 15 maio 2002. 
SEARLE, John. Expressão e significado: estudos da teoria dos atos de fala. 2. ed. São Paulo: Martins Fontes, 2002. cap. 3, p. 95-119: O estatuto lógico do discurso ficcional.

SHEPARD, Sam. Seven plays. [s.l.]: Bantam, 1984.

TRUE West, Sam Shepard.

Disponível em <http://www.sparknotes.com/drama/truewest $>$. Acesso em 23 jul. 2002. 